\title{
Action of Water on Calcium Aluminoferrites
}

\author{
Elmer T. Carlson
}

(April 30, 1964)

\begin{abstract}
The action of water on seven preparations of the calcium aluminoferrite solid solution series, ranging in composition from $6 \mathrm{CaO} \cdot 2 \mathrm{Al}_{2} \mathrm{O}_{3} \cdot \mathrm{Fe}_{2} \mathrm{O}_{3}$ to $2 \mathrm{CaO} \cdot \mathrm{Fe}_{2} \mathrm{O}_{3}$, was studied (a) by leaching the powdered preparations with water, (b) by stirring in a large volume of water at different temperatures from 10 to $100^{\circ} \mathrm{C}$, and (c) by paste hydration at 1,25 , and $45^{\circ} \mathrm{C}$.

The initial reaction occurring immediately on contact between the aluminoferrite and water is one of incongruent solution. The $\mathrm{Al}_{2} \mathrm{O}_{3}$, most of the $\mathrm{CaO}$, and a trace of $\mathrm{Fe}_{2} \mathrm{O}_{3}$ pass into solution, and a residue of $\mathrm{Fe}_{2} \mathrm{O}_{3}$, possibly hydrated and amorphous, remains. If the suspension is sufficiently concentrated to give a supersaturated solution, a hydrated precipitate will form. At room temperature the major precipitated phase is $2 \mathrm{CaO}^{-} \mathrm{Al}_{2} \mathrm{O}_{3}$. $8 \mathrm{H}_{2} \mathrm{O}$, or a limited solid solution of the same. At $70{ }^{\circ} \mathrm{C}$ a solid solution of $3 \mathrm{CaO} \cdot \mathrm{Al}_{2} \mathrm{O}_{3} \cdot 6 \mathrm{H}_{2} \mathrm{O}$, in which about one-tenth of the $\mathrm{Al}_{2} \mathrm{O}_{3}$ is replaced by $\mathrm{Fe}_{2} \mathrm{O}_{3}$, is precipitated. The rate of reaction increases with temperature and with the proportion of alumina in the aluminoferrite.

Hydration in paste form progresses in a different manner. The hydrogarnet phase produced varies in composition with the parent aluminoferrite, but is always somewhat poorer in $\mathrm{Fe}_{2} \mathrm{O}_{3}$. The hexagonal plate phase, $4 \mathrm{CaO} \cdot\left(\mathrm{Al}_{2} \mathrm{O}_{3}, \mathrm{Fe}_{2} \mathrm{O}_{3}\right) \cdot n \mathrm{H}_{2} \mathrm{O}$ is produced from the aluminoferrites high in $\mathrm{Fe}_{2} \mathrm{O}_{3}$, especially at the lower temperatures. Another platy phase, $2 \mathrm{CaO} \cdot \mathrm{Al}_{2} \mathrm{O}_{3} \cdot 8 \mathrm{H}_{2} \mathrm{O}$ (or its limited solid solution) is formed from preparations highest in $\mathrm{Al}_{2} \mathrm{O}_{3}$, also at lower temperatures. Intermediate members give chiefly the hydrogarnet phase even at $25^{\circ} \mathrm{C}$.
\end{abstract}

\section{Introduction}

The compound $4 \mathrm{CaO} \cdot \mathrm{Al}_{2} \mathrm{O}_{3} \cdot \mathrm{Fe}_{2} \mathrm{O}_{3}$ was first reported in 1928 by Hansen, Brownmiller, and Bogue $[1]^{1}$, who also demonstrated the existence of a solid solution series extending from $2 \mathrm{CaO} \cdot \mathrm{Fe}_{2} \mathrm{O}_{3}$ to $4 \mathrm{CaO} \cdot \mathrm{Al}_{2} \mathrm{O}_{3} \cdot \mathrm{Fe}_{2} \mathrm{O}_{3}\left(\mathrm{C}_{2} \mathrm{~F} \text { to } \mathrm{C}_{4} \mathrm{AF}\right)^{2}$. Subsequent research in this area of the system $\mathrm{CaO}-\mathrm{Al}_{2} \mathrm{O}_{3}-\mathrm{Fe}_{2} \mathrm{O}_{3}$ has shown that the series extends beyond $\mathrm{C}_{4} \mathrm{AF}$ toward a hypothetical $\mathrm{C}_{2} \mathrm{~A}$, reaching at least as far as $\mathrm{C}_{6} \mathrm{~A}_{2} \mathrm{~F}$ and probably a little farther. The investigations in this field were summarized by Nurse [2] for the Fourth International Symposium on the Chemistry of Cement (1960). More recently the crystal structure has been investigated by Smith [3], who gives the generalized formula for the series as $\mathrm{Ca}_{8}\left(\mathrm{Fe}_{1-\mathrm{p}} \mathrm{Al}_{\mathrm{p}}\right)_{8} \mathrm{O}_{20} \quad(\mathrm{O} \leq \mathrm{p} \leq 0.69)$. The ternary solid solution is of importance because of its presence in portland cement clinker. The $\mathrm{Al}_{2} \mathrm{O}_{3}: \mathrm{Fe}_{2} \mathrm{O}_{3}$ ratio in the clinker varies with that in the raw mix, but it has been shown [4] that the relationship is not simple. For many clinkers the composition approximates $\mathrm{C}_{4} \mathrm{AF}$, although, according to Smith [3], the $\mathrm{C}_{4} \mathrm{AF}$ composition is not a distinct compound. The solid solution often is referred to as the ferrite phase, and is sometimes designated Fss.

The authors who first described $\mathrm{C}_{4} \mathrm{AF}$ [1] also reported on its hydraulic properties. In the ensuing years, several other investigations of the hydration \footnotetext{
1 Figures in brackets indicate the literature references at the end of this paper.
2 The abbreviated formulas commonly adopted by cement chemists $(\mathrm{C}=\mathrm{CaO}$, $\left.\mathrm{A}=\mathrm{Al}_{2} \mathrm{O}_{3}, \mathrm{~F}=\mathrm{Fe}_{2} \mathrm{O}_{3}, \mathrm{~S}=\mathrm{SiO}_{2}, \mathrm{H}=\mathrm{H}_{2} \mathrm{O}\right)$ will be used in this paper interchangeably with the conventional formulas.
}

of the ferrite phase have been made, yet the subject has by no means been as fully covered as has the hydration of the other major constituents of portland cement.

The individual hydrated compounds usually may be studied more readily on preparations synthesized by precipitation methods rather than by direct hydration of the anhydrous aluminoferrites. By such methods it has been established that there are two series of hydrated calcium aluminoferrite solid solutions, one crystallizing in the cubic system, the other in the form of hexagonal plates. The former series was described by Flint, McMurdie, and Wells in their paper on the garnet-hydrogarnet series [5]. For convenience it may be designated the $\mathrm{C}_{3} \mathrm{AH}_{6}-$ $\mathrm{C}_{3} \mathrm{FH}_{6}$ series, though it is not yet firmly established that the ferrite end member can be formed in the absence of silica. The hexagonal series, $\mathrm{C}_{4} \mathrm{AH}_{n}-$ $\mathrm{C}_{4} \mathrm{FH}_{n}$, has been studied extensively by Malquori and Cirilli [6], who also investigated the cubic series. Several other investigators have reported studies of these hydrates. Their work was summarized in 1960 by Jones [7] in a review paper prepared for the Fourth International Symposium on the Chemistry of Cement.

In the two solid solution series described, $\mathrm{Fe}_{2} \mathrm{O}_{3}$ appears to behave very much as does $\mathrm{Al}_{2} \mathrm{O}_{3}$. One might therefore expect to find hydrated ferrites analogous to the less basic aluminates, $\mathrm{C}_{2} \mathrm{AH}_{8}$ and $\mathrm{CAH}_{10}$. The existence of such compounds has indeed been suggested, but there appears to be no definite evidence for them at present [7].

Members of the two known series of solid solutions have been prepared by hydration of $\mathrm{C}_{4} \mathrm{AF}[5,6,7]$, the hexagonal plate phase being favored by lower 
temperatures, the cubic by higher. Both hydrates are richer in $\mathrm{CaO}$ than the anhydrous compound and, unless additional $\mathrm{CaO}$ is supplied, part of the $\mathrm{Al}_{2} \mathrm{O}_{3}$ or $\mathrm{Fe}_{2} \mathrm{O}_{3}$, or both, will be left over after formation of the hydrate. From numerous investigations of the calcium aluminates, excess $\mathrm{Al}_{2} \mathrm{O}_{3}$ would be expected to form an amorphous hydrated gel, gradually converting to gibbsite. The composition of the excess $\mathrm{Fe}_{2} \mathrm{O}_{3}$ appears to be still in question. It may be present as hematite or a crystalline hydrate of $\mathrm{Fe}_{2} \mathrm{O}_{3}$, a ferric hydroxide gel, or a combination of these [7].

In the series $\mathrm{C}_{4} \mathrm{AH}_{n}-\mathrm{C}_{4} \mathrm{FH}_{n}$, the value of $n$ is not entirely certain. In $\mathrm{C}_{4} \mathrm{~A} \mathrm{H}_{n}$, it has been shown recently that $n=19$ for crystals in contact with the aqueous solution, but falls to 13 with only moderate drying [8]. For $\mathrm{C}_{4} \mathrm{FH}_{n}$, the value of 14 for $n$ has been suggested [7]. with information lacking as to a higher hydrate. No attempt is made herein to settle this point.

The paste hydration of $\mathrm{C}_{4} \mathrm{AF}$ at room temperature has been investigated recently by Chatterji and Jeffery [9] by means of electron-optical and $\mathrm{x}$-ray diffraction techniques. It was shown that the initial hydration product contained the hexagonal compounds, $\mathrm{C}_{4} \mathrm{AH}_{n}$ and $\mathrm{C}_{2} \mathrm{AH}_{n}$, with the cubic $\mathrm{C}_{3} \mathrm{AH}_{6}$ appearing after 14 days. Substitution of $\mathrm{Fe}$ for $\mathrm{Al}$ in the $\mathrm{C}_{4} \mathrm{AH}_{n}$ was indicated by enlargement of the unit cell parameter, $a$. Similar substitution in $\mathrm{C}_{3} \mathrm{AH}_{6}$ was observed only in the presence of added lime.

Although there is considerable knowledge of the hydration of $\mathrm{C}_{4} \mathrm{AF}$, relatively little has been done in comparing other members of the aluminoferrite series. It is known in a general way that the reactivity with water is less rapid as the iron content is increased. Midgley, Rosaman, and Fletcher [10] have presented data for the relative rates of solution of $\mathrm{C}_{6} \mathrm{AF}_{2}, \mathrm{C}_{4} \mathrm{AF}$, and $\mathrm{C}_{6} \mathrm{~A}_{2} \mathrm{~F}$ in ammoniacal ammonium citrate solution; the rate increases markedly in the order given. No comparable data for reactivity with pure water have been noted. A study of the reactions of the aluminoferrites with a large excess of water is needed to provide a better understanding of the more practical problems of their reactions in paste form and of their interaction with other cement compounds. The present paper describes research which deals mainly with reactions of the aluminoferrites in excess water, and with one series of pastetype reaction mixtures.

\section{Materials and Procedures}

A series of sintered preparations covering the range from $6 \mathrm{CaO} \cdot 2 \mathrm{Al}_{2} \mathrm{O}_{3} \cdot \mathrm{Fe}_{2} \mathrm{O}_{3}$ to $2 \mathrm{CaO} \cdot \mathrm{Fe}_{2} \mathrm{O}_{3}\left(\mathrm{C}_{6} \mathrm{~A}_{2} \mathrm{~F}\right.$ to $\mathrm{C}_{2} \mathrm{~F}$ ) were made in approximately 100 -gram lots. The raw materials, reagent grade calcium carbonate (low alkali), aluminum hydroxide (gibbsite), and ferric oxide, were mixed dry, passed through a No. 48 sieve, and again mixed dry for two hours in bottles on a rotating wheel. The mixtures were then heated in open platinum dishes in an electric furnace at $1320{ }^{\circ} \mathrm{C}$ for two to three hours, cooled, ground, and reheated in the same manner. Each preparation was ground to pass a No. 200 sieve and was then separated into two fractions with a No. 325 sieve. All the sinters except that of $\mathrm{C}_{6} \mathrm{~A}_{2} \mathrm{~F}$ were friable and easy to grind. The $\mathrm{C}_{0} \mathrm{~A}_{2} \mathrm{~F}$ preparation was partially fused.

The preparations were analyzed for $\mathrm{Al}_{2} \mathrm{O}_{3}, \mathrm{Fe}_{2} \mathrm{O}_{3}$, and $\mathrm{CaO}$ in accordance with Federal Test Method Standard No. 158a [11]. Ferrous iron was determined by dichromate titration of a sample dissolved in hydrochloric acid in an atmosphere of carbon dioxide. Free $\mathrm{CaO}$ was determined by the glycerolalcohol-ammonium acetate method. The results of the analyses are given in table 1. X-ray diffraction patterns of the powdered sinters, obtained on an $\mathrm{x}$-ray diffractometer with $\mathrm{Cu} \mathrm{K} \alpha$ radiation, were in good agreement with published patterns. The surface area of the fractions passing the No. 325 sieve was determined by the air permeability method [12]. The values are given in the last column of table 1 . The fractions retained on the No. 325 sieve were not measured for surface area, being outside the working range of the apparatus.

TABLE 1. Chemical composition and specific surface of aluminoferrite preparations

\begin{tabular}{|c|c|c|c|c|c|c|c|}
\hline $\begin{array}{l}\text { Lot desig- } \\
\text { nation }\end{array}$ & $\begin{array}{l}\text { Nominal com- } \\
\text { position a }^{\text {a }}\end{array}$ & $\mathrm{CaO}$ & $\mathrm{Al}_{2} \mathrm{O}_{3}$ & $\mathrm{Fe}_{2} \mathrm{O}_{3}$ & $\mathrm{FeO}$ & $\begin{array}{l}\text { Free } \\
\mathrm{CaO}\end{array}$ & $\begin{array}{l}\text { Specific } \\
\text { surface } \\
\text { of fine } \\
\text { fraction }\end{array}$ \\
\hline $\begin{array}{l}\text { Fss-1 } \\
\text { Fss-2 } \\
\text { Fss-3 }\end{array}$ & $\begin{array}{c}\mathrm{C}_{6} \mathrm{~A}_{2} \mathrm{~F} \\
\mathrm{C}_{6} \mathrm{~A}_{1.75} \mathrm{~F}_{1.25} \\
\mathrm{C}_{6} \mathrm{~A}_{1.5} \mathrm{~F}_{1.5}\end{array}$ & $\begin{array}{l}\% \\
48.2 \\
47.1 \\
46.3\end{array}$ & $\begin{array}{l}\% \\
28.8 \\
24.4 \\
21.0\end{array}$ & $\begin{array}{l}\% \\
23.3 \\
28.5 \\
32.8\end{array}$ & $\begin{array}{c}\% \\
-1\end{array}$ & $\begin{array}{r}\% \\
<0.01 \\
<.01 \\
.02\end{array}$ & $\begin{array}{l}c m^{2} / g \\
1800 \\
1200 \\
1180\end{array}$ \\
\hline $\begin{array}{l}\text { Fss-4 } \\
\text { Fss-5 } \\
\text { Fss-6 } \\
\mathrm{C}_{2} \mathrm{~F}-1\end{array}$ & $\begin{array}{c}\mathrm{C}_{6} \mathrm{~A}_{1.25} \mathrm{~F}_{1.75} \\
\mathrm{C}_{6} \mathrm{AF}_{2} \\
\mathrm{C}_{6} \mathrm{~A}_{0.5} \mathrm{~F}_{2.5} \\
\mathrm{C}_{2} \mathrm{~F}\end{array}$ & $\begin{array}{l}45.2 \\
44.3 \\
42.6 \\
41.1\end{array}$ & $\begin{array}{r}17.3 \\
13.5 \\
6.4 \\
0.0\end{array}$ & $\begin{array}{l}37.5 \\
42.1 \\
51.0 \\
59.1\end{array}$ & $\begin{array}{l}0.03 \\
.07 \\
.07\end{array}$ & $\begin{array}{r}.28 \\
.01 \\
.04 \\
<.01\end{array}$ & $\begin{array}{l}890 \\
830 \\
640 \\
630\end{array}$ \\
\hline
\end{tabular}

s $\mathrm{C}=\mathrm{CaO} ; \mathrm{A}=\mathrm{Al}_{2} \mathrm{O}_{3} ; \mathrm{F}=\mathrm{Fe}_{2} \mathrm{O}_{3}$.

For the experiments described under section 3.1, as well as for certain exploratory tests, a series of preparations made earlier were used. They were comparable to lots Fss $-1,-3$, and -5 in composition, but were ground only to pass a No. 100 sieve.

Distilled water for the solution experiments was boiled before use to expel carbon dioxide. For the experiments described under section $3.2,1 \mathrm{~g}$ of the sample was added to 1 liter of water in a flask and continuously stirred for several hours. The flask was immersed in a water bath maintaining constant temperature to about $\pm 0.2^{\circ} \mathrm{C}$ at $25^{\circ} \mathrm{C}$, and $0.8^{\circ} \mathrm{C}$ at $45^{\circ} \mathrm{C}$. At intervals, portions of the suspension were removed by suction, filtered through a fritted glass crucible in a closed system, and analyzed. Preliminary experiments showed that sorption of calcium hydroxide by the fritted glass, though detectable, was too slight to be significant in the present work.

\section{Experimental Results}

\subsection{Leaching Experiments}

The first series of experiments was designed to permit analysis of the solution after very brief 
contact between the solid and the water, without regard to close control of either time or temperature. The water was poured over a bed of the powdered sample in a fritted glass crucible fitted to a suction flask, and the filtrate was analyzed. In preliminary tests, the bed of powder was first given an alcohol wash to eliminate fine particles that might go through the filter as such. Evaporation of the alcohol left residues of the order of only $0.1 \mathrm{mg}$; hence the alcohol wash was omitted thereafter.

The water was added from a pipet, except for the boiling water which was simply poured on. The approximate duration of the leaching period was recorded. The time varied considerably, partly because of variability among crucibles, partly because they became clogged to varying degrees. In some cases the rate was controlled by the delivery speed of the pipet; in others the crucible was slower, and the water accumulated to a depth of $5 \mathrm{~mm}$ or more above the bed. A few parallel experiments indicated that a longer leaching period allowed more material to dissolve but did not affect the ratio of the components in solution. This result was further checked by making successive leachings through the same bed with $50-\mathrm{ml}$ portions of water. The first two filtrates were of about the same concentration, the third and fourth progressively more dilute, but the ratio of $\mathrm{CaO}$ to $\mathrm{Al}_{2} \mathrm{O}_{3}$ was approximately constant.

In a separate test it was found that the very first drops passing through the bed of solid on the filter were alkaline to phenolphthalein, showing that there was no "induction period" of appreciable duration.

The filtrates were analyzed for $\mathrm{CaO}$ and $\mathrm{Al}_{2} \mathrm{O}_{3}$ by conventional gravimetric methods. At first, qualitative tests for $\mathrm{Fe}_{2} \mathrm{O}_{3}$ were made by the thiocyanate method, but the results were always negative, and the test was subsequently omitted.

Results of a series of experiments of this type are given in table 2. Among other things, variation of the temperature of the leaching water was investigated. The temperatures indicated refer to the water at the start of leaching. Since the ambient temperature was about $25^{\circ} \mathrm{C}$, the actual temperature varied in that direction during the run. Blank tests showed that the water at $1{ }^{\circ} \mathrm{C}$ warmed to about 5 ${ }^{\circ} \mathrm{C}$, while that at 50 and 100 cooled to about 45 and $85{ }^{\circ} \mathrm{C}$, respectively, before the end of the leaching period. For the present purpose, this variation in temperature was of no concern.

From the results obtained, the following conclusions may be drawn. (1) the amount of iron going into solution is too slight to detect by the method used. (2) The ratio of $\mathrm{CaO}$ to $\mathrm{Al}_{2} \mathrm{O}_{3}$ is lower in the solution than in the solid in all cases, and the difference increases as the $\mathrm{CaO}: \mathrm{Al}_{2} \mathrm{O}_{3}$ ratio in the solid increases. (3) The $\mathrm{CaO}: \mathrm{Al}_{2} \mathrm{O}_{3}$ ratio of the solution shows no consistent trend with temperature. The relatively large spread in values for the $\mathrm{C}_{6} \mathrm{AF}_{2}$ group may be ascribed to experimental errors, as the concentrations here were rather low. (4) The rate of reaction increases with temperature, as expected.
TABLE 2. Results of some leaching experiments on three calcium aluminoferrites

\begin{tabular}{|c|c|c|c|c|c|c|c|c|}
\hline $\begin{array}{c}\text { Expt. } \\
\text { No. }\end{array}$ & $\begin{array}{l}\text { Compo- } \\
\text { sition of } \\
\text { solid a }\end{array}$ & $\begin{array}{l}\text { Weight } \\
\text { of solid }\end{array}$ & $\begin{array}{l}\text { Volume } \\
\text { of } \mathrm{H}_{2} \mathrm{O}\end{array}$ & $\begin{array}{c}\text { Tempera- } \\
\text { ture b }\end{array}$ & $\begin{array}{c}\text { Leach- } \\
\text { ing } \\
\text { time }\end{array}$ & $\begin{array}{l}\mathrm{Al}_{2} \mathrm{O}_{3} \text { in } \\
\text { solution }\end{array}$ & $\begin{array}{l}\mathrm{CaO} \text { in } \\
\text { solution }\end{array}$ & 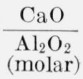 \\
\hline $\begin{array}{l}1 \\
2 \\
3 \\
4\end{array}$ & $\begin{array}{l}\mathrm{C}_{6} \mathrm{~A}_{2} \mathrm{~F} \\
\mathrm{C}_{6} \mathrm{~A}_{2} \mathrm{~F} \\
\mathrm{C}_{6} \mathrm{~A}_{2} \mathrm{~F} \\
\mathrm{C}_{6} \mathrm{~A}_{2} \mathrm{~F}\end{array}$ & $\begin{array}{c}g \\
0.50 \\
1.00 \\
0.25 \\
.25\end{array}$ & $\begin{array}{l}m l \\
100 \\
100 \\
100 \\
100\end{array}$ & $\begin{array}{r}{ }^{\circ} C \\
1 \\
25 \\
50 \\
100\end{array}$ & $\begin{array}{l}s e c \\
125 \\
160 \\
36 \\
45\end{array}$ & $\begin{array}{l}g / \text { liter } \\
0.053 \\
.182 \\
.080 \\
.123\end{array}$ & $\begin{array}{c}\text { g/liter } \\
0.081 \\
.267 \\
.116 \\
.172\end{array}$ & $\begin{array}{l}2.8 \\
2.7 \\
2.6 \\
2.5\end{array}$ \\
\hline $\begin{array}{l}5 \\
6 \\
7 \\
8\end{array}$ & $\begin{array}{l}\mathrm{C}_{4} \mathrm{AF} \\
\mathrm{C}_{4} \mathrm{AF} \\
\mathrm{C}_{4} \mathrm{AF} \\
\mathrm{C}_{4} \mathrm{AF}\end{array}$ & $\begin{array}{l}1.00 \\
1.00 \\
1.00 \\
1.00\end{array}$ & $\begin{array}{l}100 \\
100 \\
100 \\
100\end{array}$ & $\begin{array}{r}1 \\
25 \\
50 \\
100\end{array}$ & $\begin{array}{r}130 \\
120 \\
90 \\
45\end{array}$ & $\begin{array}{l}.016 \\
.078 \\
.126 \\
.211\end{array}$ & $\begin{array}{l}.028 \\
.141 \\
.229 \\
.390\end{array}$ & $\begin{array}{l}3.2 \\
3.4 \\
3.3 \\
3.4\end{array}$ \\
\hline $\begin{array}{r}9 \\
10 \\
11 \\
12\end{array}$ & $\begin{array}{l}\mathrm{C}_{6} \mathrm{AF}_{2} \\
\mathrm{C}_{6} \mathrm{AF}_{2} \\
\mathrm{C}_{6} \mathrm{AF}_{2} \\
\mathrm{C}_{6} \mathrm{AF}_{2}\end{array}$ & $\begin{array}{l}1.00 \\
1.00 \\
1.00 \\
1.00\end{array}$ & $\begin{array}{l}100 \\
100 \\
100 \\
100\end{array}$ & $\begin{array}{r}1 \\
25 \\
50 \\
100\end{array}$ & $\begin{array}{r}80 \\
160 \\
38 \\
40\end{array}$ & $\begin{array}{l}.008 \\
.038 \\
.048 \\
.098\end{array}$ & $\begin{array}{l}.017 \\
.073 \\
.107 \\
.236\end{array}$ & $\begin{array}{l}3.9 \\
3.5 \\
4.0 \\
4.4\end{array}$ \\
\hline
\end{tabular}

a $\mathrm{C}=\mathrm{CaO} ; \mathrm{A}=\mathrm{Al}_{2} \mathrm{O}_{3} ; \mathrm{F}=\mathrm{Fe}_{2} \mathrm{O}_{3}$.

b Temperature of water at start of leaching. The temperature in the funnel moved progressively toward ambient temperature (about $25^{\circ} \mathrm{C}$ ) during the leaching.

Although the leaching process took from 36 to 160 sec, it is clear that the first drops coming through had been in contact with the solid for a much shorter period, probably of the order of 0.1 sec. Any $\mathrm{Fe}_{2} \mathrm{O}_{3}$ that dissolved and remained in solution as long as 0.1 sec would be expected to appear in detectable amount in the filtrate. However, none was found. From this it appears that the reaction after the first $0.1 \mathrm{sec}$ of contact, approximately, is not essentially different from that occurring after several minutes. It was necessary to establish that point before proceeding to the next type of experiment, which was capable of closer control but could not yield reliable data for periods shorter than about $2 \mathrm{~min}$.

\subsection{Solution Experiments With Sampling at Several Intervals}

The general procedure used was described in section 2, above. The fine fractions of preparations Fss-1 to Fss-6 (see table 1) were used in amounts of $1 \mathrm{~g} /$ /iter of water. This proportion was chosen in the belief that the maximum concentration attained would be low enough to avoid precipitation of a calcium aluminate hydrate. However, there was some evidence of precipitation in one or two cases before the tests were terminated. As in the work described in the previous section, some of the earlier filtrates were tested qualitatively for iron. None was detected, and the test for iron was discontinued.

Table 3 gives the data obtained in a typical run. The figures in the fourth column show that the ratio of $\mathrm{CaO}$ to $\mathrm{Al}_{2} \mathrm{O}_{3}$ in solution does not change significantly with time. Also, they are in good agreement with the corresponding values in table 2 . As the ratio of $\mathrm{CaO}$ to $\mathrm{Al}_{2} \mathrm{O}_{3}$ in the solid was $3: 1$, and that in the solution somewhat lower, it is clear that some $\mathrm{CaO}$ remained in the residue with the $\mathrm{Fe}_{2} \mathrm{O}_{3}$. Analy . sis of a portion of the residue also showed some $\mathrm{Al}_{2} \mathrm{O}_{3}$. The data here give no indication as to whether the residual $\mathrm{Al}_{2} \mathrm{O}_{3}$ represents unaltered an- 
hydrous material or a reaction product. However, in similar experiments using a smaller original quantity of solid, or continued for a longer period, the residual $\mathrm{Al}_{2} \mathrm{O}_{3}$ was reduced to zero. It is assumed, therefore, that the $\mathrm{Al}_{2} \mathrm{O}_{3}$ that was not found in solution was present in unreacted grains of anhydrous solid. On this basis, the weight fraction that had reacted was calculated (last column).

TABLE 3. Data relative to the reaction between $6 \mathrm{CaO} \cdot 2 \mathrm{Al}_{2} \mathrm{O}_{3}$. $\mathrm{Fe}_{2} \mathrm{O}_{3}$ and water

(Preparation Fss-1; $1.00 \mathrm{~g} ; 1$ liter $\mathrm{H}_{2} \mathrm{O}$; temperature $24.3 \pm 0.2{ }^{\circ} \mathrm{C}$ )

\begin{tabular}{|c|c|c|c|c|}
\hline Time ${ }^{a}$ & $\begin{array}{l}\mathrm{Al}_{2} \mathrm{O}_{3} \text { in } \\
\text { solution }\end{array}$ & $\begin{array}{l}\mathrm{CaO} \text { in } \\
\text { solution }\end{array}$ & $\underset{\text { (molar) }}{\mathrm{CaO}: \mathrm{Al}_{2} \mathrm{O}_{3}}$ & $\begin{array}{l}\text { Weight fraction } \\
\text { reacted } \mathrm{b}\end{array}$ \\
\hline $\begin{array}{r}2 \mathrm{~min} \\
5 \mathrm{~min} \\
11 \mathrm{~min} \\
20 \mathrm{~min}\end{array}$ & $\begin{array}{c}g / \text { liter } \\
0.073 \\
.138 \\
.160 \\
.181\end{array}$ & $\begin{array}{c}g / \text { liter } \\
0.114 \\
.192 \\
.225 \\
.250\end{array}$ & $\begin{array}{l}2.8 \\
2.5 \\
2.6 \\
2.5\end{array}$ & $\begin{array}{r}0.25 \\
.48 \\
.55 \\
.62\end{array}$ \\
\hline $\begin{array}{c}60 \mathrm{~min} \\
3 \mathrm{hr} \\
7 \mathrm{hr} \\
23 \mathrm{hr}\end{array}$ & $\begin{array}{l}.204 \\
.227 \\
.247 \\
.254\end{array}$ & $\begin{array}{l}.300 \\
.345 \\
.386 \\
.392\end{array}$ & $\begin{array}{l}2.7 \\
2.8 \\
2.8 \\
2.8\end{array}$ & $\begin{array}{l}.70 \\
.78 \\
.85 \\
.88\end{array}$ \\
\hline
\end{tabular}

a Interval between addition of powder to water and start of removal of sample of solution through filter. Filtration required 1-2 minutes. Average period of contact for the sample may therefore be as much as 1 min longer than indicated in column 1 .

bBased on $\mathrm{Al}_{2} \mathrm{O}_{3}$ in solution in relation to total $\mathrm{Al}_{2} \mathrm{O}_{3}$ present. (See text for discussion.)

The ratio of $\mathrm{CaO}$ attached to the $\mathrm{Fe}_{2} \mathrm{O}_{3}$ in the residue was calculated from the $\mathrm{CaO}: \mathrm{Al}_{2} \mathrm{O}_{3}$ ratio in table 3 , with the same assumption regarding residual $\mathrm{Al}_{2} \mathrm{O}_{3}$; it amounted to 0.7 mole $\mathrm{CaO}$ per mole $\mathrm{Fe}_{2} \mathrm{O}_{3}$.

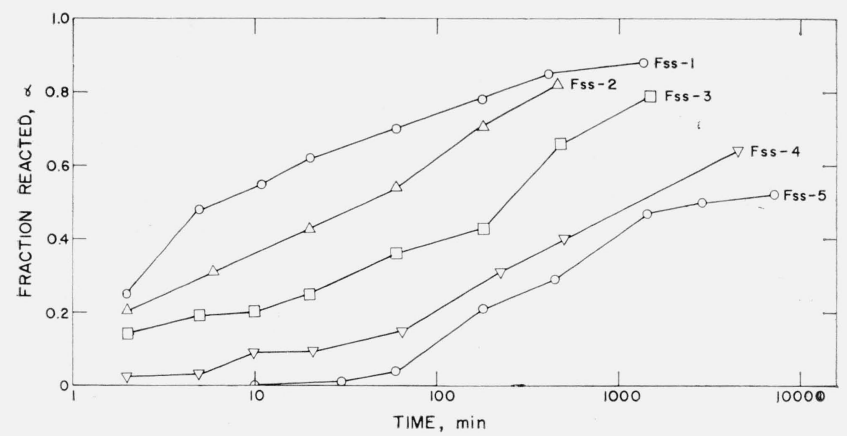

Figure 1. Progress of reaction between calcium aluminoferrite preparations and water as a function of time of stirring. 1 gram per liter; $25^{\circ} \mathrm{C}$.

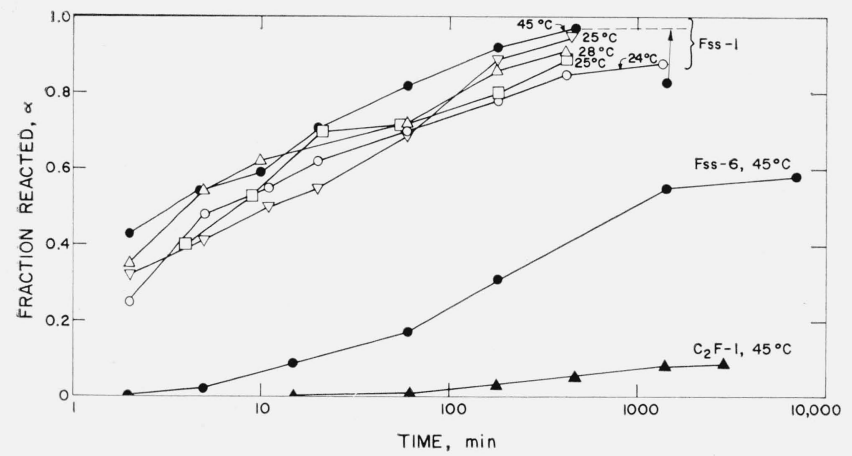

Figure 2. Progress of reaction between calcium aluminoferrite preparations and water as a function of time of stirring. 1 gram per liter; temperatures indicated.
The data in the first and last columns of table 3 are plotted in figure 1 (upper curve) to give a clearer picture of the course of the reaction. The ordinate is the weight fraction of solid that has reacted $(\alpha)$, computed on the basis of the $\mathrm{Al}_{2} \mathrm{O}_{3}$ in solution. The other curves in figure 1 are derived from experiments with preparations $\mathrm{Fss}-2$ to $\mathrm{Fss}-5$. The decrease in reactivity with increase in $\mathrm{Fe}_{2} \mathrm{O}_{3}: \mathrm{Al}_{2} \mathrm{O}_{3}$ ratio is apparent, though it should be borne in mind that part of the observed difference must be attributed to the differences in specific surface (table 1). Preparation Fss-6 reacted so slowly at $25{ }^{\circ} \mathrm{C}$ that it was decided to raise the temperature to $45^{\circ} \mathrm{C}$. The results are plotted in figure 2, second curve from bottom. The end member of the series, $\mathrm{C}_{2} \mathrm{~F}$, reacted still more slowly (see bottom curve). Since this preparation contained no $\mathrm{Al}_{2} \mathrm{O}_{3}$, the progress of the reaction was estimated from the $\mathrm{CaO}$ in solution.

The upper group of curves in figure 2 represents five separate runs with preparation Fss-1, including the one already shown in figure 1 . The purpose here is twofold, to give some idea of the reproducibility and to show the effect of temperature. From the random nature of the deviations from smooth curves, it may be assumed that these deviations reflect irregularities in the procedure (stirring speed or rate of filtering) or errors in analysis. It is apparent that the increase in temperature from 25 to $45{ }^{\circ} \mathrm{C}$ has a relatively small effect on the progress of the reaction of the aluminoferrite with water, though the difference is appreciable at the earliest sampling interval. The apparent drop in $\alpha$ between 8 and 24 hours (last 2 points, top curve) should be noted. This resulted from precipitation of $\mathrm{Al}_{2} \mathrm{O}_{3}$ (and $\mathrm{CaO}$ ) from the supersaturated solution. The precipitate had a molar $\mathrm{CaO}: \mathrm{Al}_{2} \mathrm{O}_{3}$ ratio of $2.2: 1$, calculated from the decrease in concentration.

The ratio of $\mathrm{CaO}$ to $\mathrm{Al}_{2} \mathrm{O}_{3}$ in the filtrate showed no consistent change with the progress of the reaction, though there were random deviations from the average. Table 4 gives the average $\mathrm{CaO}: \mathrm{Al}_{2} \mathrm{O}_{3}$ ratios in the filtrate for each of the experiments included in figures 1 and 2. The ratio of $\mathrm{CaO}$ to $\mathrm{Fe}_{2} \mathrm{O}_{3}$ in the residue, calculated as described previously, is also given in table 4 .

TABLE 4. Ratio of $\mathrm{CaO}$ to $\mathrm{Al}_{2} \mathrm{O}_{3}$ in solution and of $\mathrm{CaO}$ to $\mathrm{Fe}_{2} \mathrm{O}_{3}$ in the residue for several solution experiments with calcium aluminoferrites

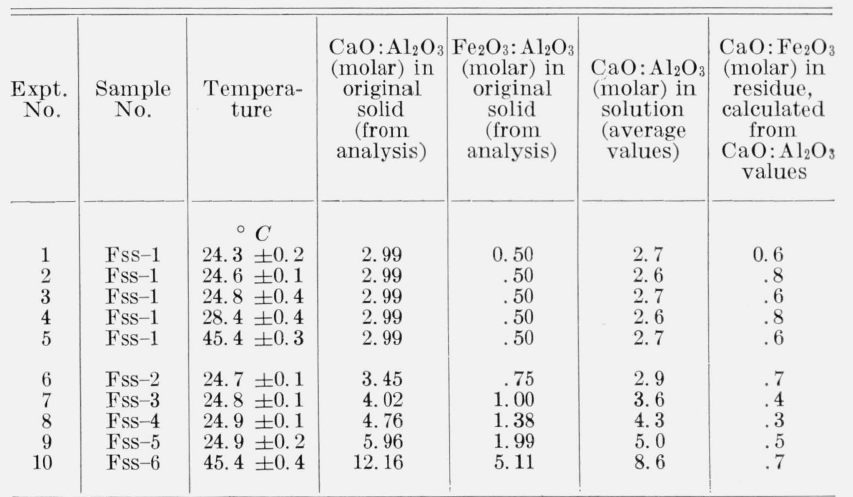


The $\mathrm{CaO}: \mathrm{Fe}_{2} \mathrm{O}_{3}$ ratio in the residue does not show any consistent trend with the composition of the aluminoferrite. There are random variations which may be attributed to uncertainties involved in the method of calculation. At this point the data do not indicate whether the $\mathrm{CaO}$ is combined with $\mathrm{Fe}_{2} \mathrm{O}_{3}$ or adsorbed.

\subsection{Effect of Temperature}

The foregoing series of experiments showed that the nature of the reaction between the calcium aluminoferrites and a large amount of water is essentially the same after several hours or days as it is at the very beginning. For most of the subsequent studies, therefore, the prolonged reaction period was replaced by a shorter procedure in which the reaction mixture was filtered for analysis only once, after 60 min. The temperature was varied in 5 steps from $10{ }^{\circ} \mathrm{C}$ to boiling, but the less reactive preparations were not tested at the lower temperatures. Except for the experiments at $10^{\circ} \mathrm{C}$, a magnetic stirrer with heater was substituted for the apparatus described previously. The initial ratio of solid to water was kept constant at $1 \mathrm{~g}$ /liter except for the experiments at the boiling point, for which it was lowered to $0.75 \mathrm{~g}$ /liter in an attempt to avoid precipitation of calcium aluminates from solution. In spite of this, a slight precipitate was observed to form on the flask walls in several instances.

TABLE 5. Solutions obtained from reaction of calcium aluminoferrites (fine fraction) with large amounts of water for 60 minutes

\begin{tabular}{|c|c|c|c|c|c|c|c|}
\hline $\begin{array}{l}\text { Expt. } \\
\text { No. }\end{array}$ & $\begin{array}{l}\text { Prepn. } \\
\text { No. }\end{array}$ & $\begin{array}{l}\text { Wt. of } \\
\text { solid }\end{array}$ & $\begin{array}{c}\text { Vol. of } \\
\mathrm{H}_{2} \mathrm{O}\end{array}$ & Temp.a & $\begin{array}{l}\mathrm{Al}_{2} \mathrm{O}_{3} \text { in } \\
\text { filtrate }\end{array}$ & $\begin{array}{l}\mathrm{CaO} \text { in } \\
\text { filtrate }\end{array}$ & $\begin{array}{c}\mathrm{CaO}: \mathrm{Al}_{2} \mathrm{O}_{3} \\
\text { Ratio } \\
\text { (molar) }\end{array}$ \\
\hline $\begin{array}{r}1 \\
2 \\
3 \\
4 \\
\mathrm{~b} 5\end{array}$ & $\begin{array}{l}\text { Fss-1 } \\
\text { Fss- }-1 \\
\text { Fss-1 } \\
\text { Fss-1 } \\
\text { Fss-1 }\end{array}$ & $\begin{array}{c}g \\
0.50 \\
.20 \\
.20 \\
.20 \\
.15\end{array}$ & $\begin{array}{l}m l \\
500 \\
200 \\
200 \\
200 \\
200\end{array}$ & $\begin{array}{r}{ }^{\circ} \mathrm{C} \\
10 \\
25 \\
45 \\
70 \\
100\end{array}$ & $\begin{array}{r}\text { g/liter } \\
0.197 \\
.202 \\
.233 \\
.248 \\
.164\end{array}$ & $\begin{array}{r}\text { g/liter } \\
0.292 \\
.304 \\
.368 \\
.382 \\
.259\end{array}$ & $\begin{array}{l}2.7 \\
2.7 \\
2.9 \\
2.8 \\
2.9\end{array}$ \\
\hline $\begin{array}{r}6 \\
7 \\
8 \\
9 \\
\mathrm{~b} 10\end{array}$ & $\begin{array}{l}\text { Fss-2 } \\
\text { Fss-2 } \\
\text { Fss-2 } \\
\text { Fss-2 } \\
\text { Fss-2 }\end{array}$ & $\begin{array}{l}.35 \\
.20 \\
.20 \\
.20 \\
.15\end{array}$ & $\begin{array}{l}350 \\
200 \\
200 \\
200 \\
200\end{array}$ & $\begin{array}{r}10 \\
25 \\
45 \\
70 \\
100\end{array}$ & $\begin{array}{l}.102 \\
.124 \\
.190 \\
.222 \\
.124\end{array}$ & $\begin{array}{l}.170 \\
.216 \\
.323 \\
.387 \\
.236\end{array}$ & $\begin{array}{l}3.0 \\
3.2 \\
3.1 \\
3.2 \\
3.5\end{array}$ \\
\hline $\begin{array}{r}11 \\
12 \\
13 \\
14 \\
\text { b15 }\end{array}$ & $\begin{array}{l}\text { Fss-3 } \\
\text { Fss-3 } \\
\text { Fss-3 } \\
\text { Fss-3 } \\
\text { Fss-3 }\end{array}$ & $\begin{array}{l}.50 \\
.20 \\
.20 \\
.20 \\
.15\end{array}$ & $\begin{array}{l}500 \\
200 \\
200 \\
200 \\
200\end{array}$ & $\begin{array}{r}10 \\
25 \\
45 \\
70 \\
100\end{array}$ & $\begin{array}{l}.054 \\
.070 \\
.134 \\
.177 \\
.144\end{array}$ & $\begin{array}{l}.102 \\
.138 \\
.257 \\
.350 \\
.314\end{array}$ & $\begin{array}{l}3.4 \\
3.6 \\
3.5 \\
3.6 \\
4.0\end{array}$ \\
\hline $\begin{array}{r}16 \\
17 \\
18 \\
\mathrm{~b} 19\end{array}$ & $\begin{array}{l}\text { Fss-4 } \\
\text { Fss-4 } \\
\text { Fss-4 } \\
\text { Fss-4 }\end{array}$ & $\begin{array}{l}.20 \\
.20 \\
.20 \\
.15\end{array}$ & $\begin{array}{l}200 \\
200 \\
200 \\
200\end{array}$ & $\begin{array}{r}25 \\
45 \\
70 \\
100\end{array}$ & $\begin{array}{l}.034 \\
.074 \\
.128 \\
.092\end{array}$ & $\begin{array}{l}.078 \\
.165 \\
.292 \\
.247\end{array}$ & $\begin{array}{l}\text { 4. } 2 \\
4.1 \\
4.2 \\
4.9\end{array}$ \\
\hline $\begin{array}{r}20 \\
21 \\
22 \\
\mathrm{~b} 23\end{array}$ & $\begin{array}{l}\text { Fss-5 } \\
\text { Fss-5 } \\
\text { Fss-5 } \\
\text { Fss-5 }\end{array}$ & $\begin{array}{l}.20 \\
.20 \\
.20 \\
.15\end{array}$ & $\begin{array}{l}200 \\
200 \\
200 \\
200\end{array}$ & $\begin{array}{r}25 \\
45 \\
70 \\
100\end{array}$ & $\begin{array}{l}.016 \\
.040 \\
.072 \\
.072\end{array}$ & $\begin{array}{l}.046 \\
.104 \\
.196 \\
.228\end{array}$ & $\begin{array}{l}5.5 \\
4.8 \\
5.0 \\
5.7\end{array}$ \\
\hline $\begin{array}{l}24 \\
25\end{array}$ & $\begin{array}{l}\text { Fss-6 } \\
\text { Fss-6 }\end{array}$ & $\begin{array}{l}.20 \\
.15\end{array}$ & $\begin{array}{l}200 \\
200\end{array}$ & $\begin{array}{r}70 \\
100\end{array}$ & $\begin{array}{l}.023 \\
.022\end{array}$ & $\begin{array}{l}.112 \\
.112\end{array}$ & $\begin{array}{l}8.9 \\
9.3\end{array}$ \\
\hline $\begin{array}{l}26 \\
27\end{array}$ & $\begin{array}{l}\mathrm{C}_{2} \mathrm{~F}-1 \\
\mathrm{C}_{2} \mathrm{~F}-1\end{array}$ & $\begin{array}{l}.20 \\
.15\end{array}$ & $\begin{array}{l}200 \\
200\end{array}$ & $\begin{array}{r}70 \\
100\end{array}$ & $\begin{array}{l}.000 \\
.000\end{array}$ & $\begin{array}{l}.026 \\
.038\end{array}$ & \\
\hline
\end{tabular}

a Temperatures $\pm 0.5{ }^{\circ} \mathrm{C}$ except as follows: at $10{ }^{\circ} \mathrm{C} \pm 0.2{ }^{\circ} \mathrm{C}$; at $100{ }^{\circ} \mathrm{C}$, not determined.

$\mathrm{b}$ Precipitate formed on wall of flask during boiling.

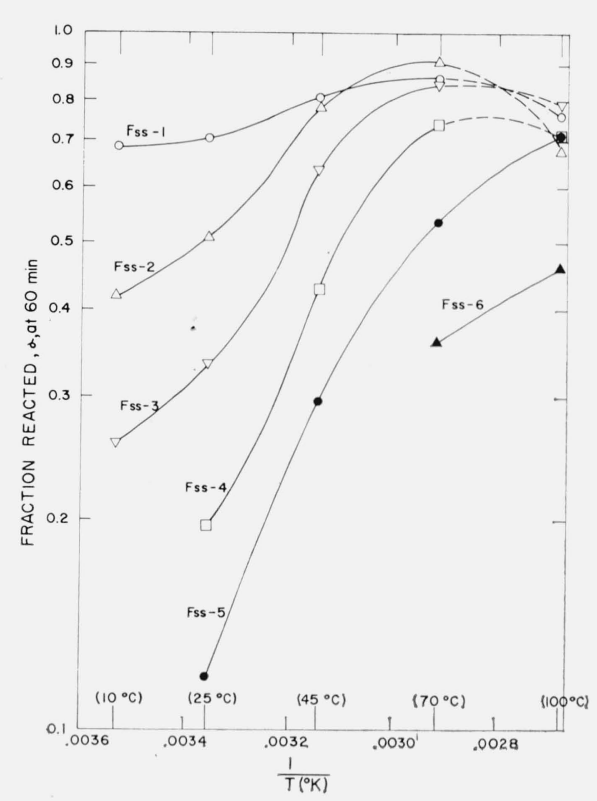

Figure 3. Progress of reaction between calcium aluminoferrite preparations and water, on stirring for 60 minutes, as a function of temperature.

1 gram per liter (except at $100{ }^{\circ} \mathrm{C}$, where ratio was 0.75 gram per liter).

The results of analyses of the filtrates are given in table 5. It may be noted that the $\mathrm{CaO}: \mathrm{Al}_{2} \mathrm{O}_{3}$ ratios for the solutions obtained by boiling are appreciably higher than the others. 'The precipitation mentioned above probably had an influence on these values. The other values for the $\mathrm{CaO}: \mathrm{Al}_{2} \mathrm{O}_{3}$ ratio are in fair agreement with those reported in tables 2 and 4 , and show no consistent trend with temperature.

The effect of temperature on the rate of solution is shown in figure 3 . Here the fraction reacted, $\alpha$, at $60 \mathrm{~min}$ is taken as a measure of the rate of the reaction, and plotted on a logarithmic scale against the reciprocal of the absolute temperature. In comparing the reactivities of the preparations, it should be noted that no correction has been made for the difference in surface area (see table 1 ).

\subsection{Effect of Calcium Hydroxide Concentration}

From the data given above (see table 3, for example) it is clear that the rate of solution falls off as the concentration increases, as would be expected. However, since this is not a case of simple solution, it is of interest to ascertain whether the reaction can be inhibited by a sufficiently high concentration of lime alone. A few tests were made with two of the preparations to obtain information on this point. Mixtures of the powdered materials were shaken with $\mathrm{Ca}(\mathrm{OH})_{2}$ solutions of different concentrations in the ratio of $1 \mathrm{~g}$ /liter for $5 \mathrm{~min}$ at $25^{\circ} \mathrm{C}$ and the filtrates were analyzed. Results are given in table 6 . It is seen that the dissolution reaction is inhibited by increasing concentration of lime, but is not completely prevented even at saturation. 
TABLE 6. Dissolution of calcium aluminoferrites in $\mathrm{Ca}(\mathrm{OH})_{2}$ solutions on shaking for 5 minutes at $25{ }^{\circ} \mathrm{C}$

Proportions: $1 \mathrm{~g}$ aluminoferrite per liter of solution

\begin{tabular}{c|c|r|r|r|r}
\hline \hline $\begin{array}{c}\text { Expt. } \\
\text { No. }\end{array}$ & $\begin{array}{c}\text { Sample } \\
\text { No. }\end{array}$ & $\begin{array}{c}\mathrm{CaO} \\
\text { concn. at } \\
\text { start }\end{array}$ & $\begin{array}{c}\mathrm{CaO} \text { in } \\
\text { soln. at } \\
5 \text { min }\end{array}$ & $\begin{array}{c}\text { Inerease in } \\
\text { CaO in } \\
\text { soln. }\end{array}$ & $\begin{array}{c}\mathrm{Al}_{2} \mathrm{O}_{3} \text { in soln. at } \\
5 \text { min }\end{array}$ \\
1 & Fss-1 & 0.000 & 0.180 & 0.180 & 0.120 \\
2 & Fss-1 & .320 & .411 & .091 & .068 \\
3 & Fss-1 & .510 & .561 & .051 & .048 \\
4 & Fss-1 & .853 & .860 & .007 & .019 \\
5 & Fss-1 & 1.150 & 1.149 & -.001 & .006 \\
6 & Fss-2 & 0.000 & 0.104 & .104 & .073 \\
7 & Fss-2 & .425 & .462 & .037 & .028 \\
8 & Fss-2 & .700 & .728 & .028 & .024 \\
9 & Fss-2 & .924 & .937 & .013 & .008 \\
\hline
\end{tabular}

\subsection{Effect of Composition on Reaction Rate}

In the preceding experiments, any comparison of the reactivities of the samples is complicated by differences in surface area. In order to minimize this variable, a series of tests were run on the fractions passing a No. 200 and retained on a No. 325 sieve, which were assumed to be equal in surface area (probably of the order of $300 \mathrm{~cm}^{2} / \mathrm{g}$ ). To compensate for the lower surface area, the ratio of solid to water was increased to about $5 \mathrm{~g} /$ liter. The actual ratio was varied to make all the mixtures equivalent on a molar basis. The mixtures were stirred $10 \mathrm{~min}$ at $25^{\circ} \mathrm{C}$, then filtered and analyzed. The data are given in table 7 . Sample Fss-1 reacted so rapidly that some precipitation occurred within the 10-min stirring period. The test therefore was repeated with one-fourth the original amount of solid (experiment 1a). Similarly, the experiment with sample Fss-2 was repeated with half the original amount. The results are shown in figure 4, in which the fraction reacted is plotted on a logarithmic scale against the initial composition of the solid expressed as $\mathrm{Al}_{2} \mathrm{O}_{3} / \mathrm{Al}_{2} \mathrm{O}_{3}+\mathrm{Fe}_{2} \mathrm{O}_{3}$. For this graph, the data for experiments $1 \mathrm{a}$ and $2 \mathrm{a}$, rather than 1 and 2 , were used, to minimize the concentration effect. This relationship will be discussed later.

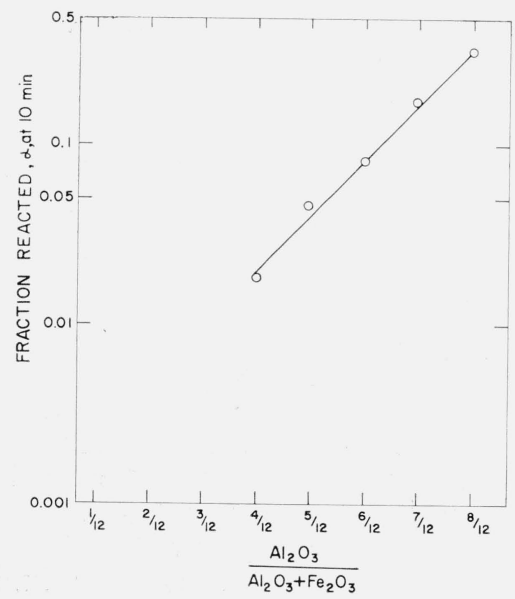

Figure 4. Reactivity of calcium aluminoferrites with water as a function of composition.
TABLE 7. Comparison of rates of solution of calcium aluminoferrites (concentrations after stirring 10 minutes at $25{ }^{\circ} \mathrm{C}$; fraction passing No. 200 and retained on No. 325 sieve)

\begin{tabular}{|c|c|c|c|c|c|c|}
\hline $\begin{array}{l}\text { Expt. } \\
\text { No. }\end{array}$ & $\begin{array}{c}\text { Sample } \\
\text { No. }\end{array}$ & $\begin{array}{l}\text { Wt. of } \\
\text { solid }\end{array}$ & $\begin{array}{l}\text { Vol. of } \\
\text { water }\end{array}$ & $\begin{array}{l}\mathrm{Al}_{2} \mathrm{O}_{3} \text { in } \\
\text { solution }\end{array}$ & $\begin{array}{l}\mathrm{CaO} \text { in } \\
\text { solution }\end{array}$ & $\begin{array}{l}\mathrm{CaO}: \mathrm{Al}_{2} \mathrm{O}_{3} \\
\text { (molar) }\end{array}$ \\
\hline $\begin{array}{l}1 \\
\text { la }\end{array}$ & $\begin{array}{l}\text { Fss-1 } \\
\text { Fss-1 }\end{array}$ & $\begin{array}{c}g \\
1.00 \\
0.25\end{array}$ & $\begin{array}{l}m l \\
200 \\
200\end{array}$ & $\begin{array}{c}g / \text { liter } \\
0.416 \\
.127\end{array}$ & $\begin{array}{c}\text { g/liter } \\
0.562 \\
.189\end{array}$ & $\begin{array}{l}2.5 \\
2.7\end{array}$ \\
\hline $\begin{array}{l}2 \\
2 \mathrm{a}\end{array}$ & $\begin{array}{l}\text { Fss-2 } \\
\text { Fss-2 }\end{array}$ & $\begin{array}{l}1.02 \\
0.51\end{array}$ & $\begin{array}{l}200 \\
200\end{array}$ & $\begin{array}{l}.151 \\
.107\end{array}$ & $\begin{array}{l}.248 \\
.182\end{array}$ & $\begin{array}{l}\text { 3. } 0 \\
3.1\end{array}$ \\
\hline $\begin{array}{l}3 \\
4\end{array}$ & $\begin{array}{l}\text { Fss-3 } \\
\text { Fss-4 }\end{array}$ & $\begin{array}{l}1.03 \\
1.05\end{array}$ & $\begin{array}{l}200 \\
200\end{array}$ & $\begin{array}{l}.087 \\
.042\end{array}$ & $\begin{array}{l}.164 \\
.094\end{array}$ & $\begin{array}{l}3.4 \\
4.1\end{array}$ \\
\hline $\begin{array}{l}5 \\
6\end{array}$ & $\begin{array}{l}\text { Fss-5 } \\
\text { Fss-6 }\end{array}$ & $\begin{array}{l}1.08 \\
1.12\end{array}$ & $\begin{array}{l}200 \\
200\end{array}$ & $\begin{array}{l}.013 \\
.000\end{array}$ & $\begin{array}{l}.037 \\
.005\end{array}$ & $\begin{array}{l}5.2 \\
---\end{array}$ \\
\hline
\end{tabular}

\subsection{Composition of Residue}

It was shown in table 4 that the reaction between $1 \mathrm{~g}$ of aluminoferrite and 1 liter of water leaves a residue containing $\mathrm{CaO}$ and $\mathrm{Fe}_{2} \mathrm{O}_{3}$ in somewhat variable ratio, with less than 1 mole of $\mathrm{CaO}$ per mole of $\mathrm{Fe}_{2} \mathrm{O}_{3}$, and with no apparent relation to the composition of the original preparation. If this product is simply an adsorption complex, the $\mathrm{CaO}: \mathrm{Fe}_{2} \mathrm{O}_{3}$ ratio should vary with the concentration of $\mathrm{CaO}$ in solution. To check this point, samples Fss-1 and Fss-2 were allowed to react with water in the ratio of $0.1 \mathrm{~g} /$ liter, one-tenth the previous amount. The concentrations of lime attained in solution were only 0.048 and $0.046 \mathrm{~g} /$ liter, respectively, as compared with 0.39 and 0.34 when $1 \mathrm{~g}$ was used. The residues, on analysis, showed $\mathrm{CaO}: \mathrm{Fe}_{2} \mathrm{O}_{3}$ ratios of 0.3 and 0.2 , respectively, as compared with the values 0.6 and 0.8 obtained at the higher concentration. This may be taken as evidence that the $\mathrm{CaO}$ is adsorbed on the $\mathrm{Fe}_{2} \mathrm{O}_{3}$, rather than chemically combined. This conclusion is confirmed, in a negative way, by the absence of any microscopic or x-ray diffraction evidence of a crystalline ferrite.

\subsection{Compounds Precipitated From Solution}

In the foregoing experiments, the ratio of solids to water was kept low to avoid precipitation. But it is important to know what solid phases would be precipitated if the concentration were increased slightly. On the assumption that the amount of $\mathrm{Fe}_{2} \mathrm{O}_{3}$ in solution is so small as to have no appreciable effect, the nature of the precipitate may be predicted from the known phase equilibria in the system $\mathrm{CaO}-\mathrm{Al}_{2} \mathrm{O}_{3}-\mathrm{H}_{2} \mathrm{O}$ [7]. The concentrations are in the range where either or both of two phases would be expected to form: (1) the metastable $\mathrm{C}_{2} \mathrm{AH}_{8}$, or its solid solution, recently reported to extend to $\mathrm{C}_{2.4} \mathrm{AH}_{n}$, crystallizing as hexagonal plates; (2) the stable isometric $\mathrm{C}_{3} \mathrm{AH}_{6}$.

To check the validity of this supposition, a series of experiments were conducted in which the ratio of solid to water was increased sufficiently to assure a moderate amount of precipitation within $20 \mathrm{~min}$. At $25^{\circ} \mathrm{C}$ only the hexagonal plate phase was observed; at $45^{\circ} \mathrm{C}$, plate crystals were present at 20 
min, isometric crystals after a few hours; at $70{ }^{\circ} \mathrm{C}$, isometric crystals plus a few plates; at boiling temperature only the isometric. These results are in accord with published data on the system $\mathrm{CaO}-\mathrm{Al}_{2} \mathrm{O}_{3}-\mathrm{H}_{2} \mathrm{O}$ [7].

The hexagonal plate phase was identified by x-ray diffraction as $\mathrm{C}_{2} \mathrm{AH}_{8}$ (or the limited solid solution mentioned above; no attempt was made to differentiate). The isometric crystals were identified by both $\mathrm{x}$-ray diffraction and microscopic observation as being of the $\mathrm{C}_{3} \mathrm{AH}_{6}$ type. However, both the refractive index and the unit cell dimensions as calculated from the diffraction pattern were slightly larger than those that have been reported for $\mathrm{C}_{3} \mathrm{AH}_{6}$. It will be recalled that $\mathrm{C}_{3} \mathrm{AH}_{6}$ may be considered an end member of a quinary solid solution series $[5,7]$ in which $\mathrm{Fe}_{2} \mathrm{O}_{3}$ may replace $\mathrm{Al}_{2} \mathrm{O}_{3}$, and $\mathrm{SiO}_{2}$ may replace $\mathrm{H}_{2} \mathrm{O}$. The $\mathrm{Fe}_{2} \mathrm{O}_{3}$ substitution results in an increase in both the refractive index and the unit cell size, while $\mathrm{SiO}_{2}$ increases the refractive index but decreases the cell dimensions.

To eliminate the possibility of contamination by $\mathrm{SiO}_{2}$ resulting from attack on glass, another series of reactions was run in polyethylene bottles. The proportion of solid was further increased, and the stirring was continued for $3-4 \mathrm{hr}$ at $70{ }^{\circ} \mathrm{C}$ to get sufficient material for accurate measurement of the diffraction patterns. This procedure also yielded crystals large enough, in a few cases at least, for an accurate determination of refractive index. A preparation of $\mathrm{C}_{3} \mathrm{~A}$ was subjected to the same treatment, and the resulting hydrate, $\mathrm{C}_{3} \mathrm{AH}_{6}$, served as a basis for comparing the other products. The unit cell dimension of the $\mathrm{C}_{3} \mathrm{AH}_{6}$, calculated from measurement of the $\mathrm{x}$-ray diffraction lines, was $12.573 \AA$. The results (see table 8) clearly show an increase in both index and cell dimensions, in comparison with $\mathrm{C}_{3} \mathrm{AH}_{6}$, which can be explained only by incorporation of $\mathrm{Fe}_{2} \mathrm{O}_{3}$ into the structure.

TABLE 8. Data pertaining to isometric crystals precipitated from solutions from aluminoferrites in polyethylene at $70{ }^{\circ} \mathrm{C}$

\begin{tabular}{|c|c|c|c|c|c|}
\hline $\begin{array}{l}\text { Prepn. } \\
\text { No. }\end{array}$ & $\begin{array}{l}\text { Wt. of } \\
\text { solid used }\end{array}$ & $\begin{array}{l}\text { Vol. of } \\
\text { water }\end{array}$ & $\begin{array}{l}\text { Index of } \\
\text { refraction }\end{array}$ & $\begin{array}{l}\text { Unit cell } \\
\text { edge, } a_{0}\end{array}$ & Remarks \\
\hline Fss-1 & ${ }_{1.0}^{g}$ & $\begin{array}{l}m l \\
500\end{array}$ & a 1.61 & $\stackrel{\AA}{\AA}$ & \\
\hline $\begin{array}{l}\text { Fss-1 } \\
\text { Fss-2 }\end{array}$ & $\begin{array}{l}1.0 \\
1.0\end{array}$ & $\begin{array}{l}500 \\
500\end{array}$ & $\begin{array}{l}1.01 \\
\text { a } 1.61\end{array}$ & $\begin{array}{l}12.591 \\
12.594\end{array}$ & \\
\hline Fss-3 & 2.0 & 500 & ^ 1.61 & 12. 585 & \\
\hline Fss-4 & 2.0 & 300 & 1.614 & 12. 594 & \\
\hline Fss-5 & 3.0 & 300 & 1.615 & 12.606 & $\begin{array}{l}\text { Some crystals of } \\
\text { higher index } \\
\text { attached to Fss }\end{array}$ \\
\hline Fss -6 & 5.0 & 300 & (b) & (b) & $\begin{array}{l}\text { grains, } \\
\text { No isometric crystals } \\
\text { observed; hexag- } \\
\text { onal plates }\end{array}$ \\
\hline $\mathrm{C}_{3} \mathrm{~A}$ & 2.0 & 500 & 1.605 & 12.573 & $\begin{array}{l}\text { Unreacted } \mathrm{C}_{3} \mathrm{~A} \text { also } \\
\text { present. }\end{array}$ \\
\hline
\end{tabular}

a Crystals too small to permit an accurate determination of index.

b No isometric crystals observed; $x$-ray pattern indicated probable presence in amount too slight for measurement of cell constant.

The relation between $\mathrm{Fe}_{2} \mathrm{O}_{3}: \mathrm{Al}_{2} \mathrm{O}_{3}$ ratio, index of refraction, and cell parameter is not known with sufficient precision to permit anything better than an estimate of the amount of $\mathrm{Fe}_{2} \mathrm{O}_{3}$ present. Assumption of a linear relation between the composition and index of refraction leads to the conclusion that the $\mathrm{Fe}_{2} \mathrm{O}_{3}$ constitutes about one-tenth of the total " $\mathrm{R}_{2} \mathrm{O}_{3}$ " on a molar basis. Consideration of the unit cell size leads to a similar conclusion. Also, the ratio of the intensities of the 220 and 611 diffraction lines, recommended as a criterion by Zur Strassen, as reported by Jones [7], is compatible with this estimate.

Within the limits of precision of the measurements there was no apparent variation in composition of the isometric phase with the composition of the parent aluminoferrite, at least for the first four preparations. The fifth, Fss-5, yielded a product with appreciably larger cell size, but there was some broadening of the x-ray diffraction lines, possibly reflecting a variability in composition. Microscopic examination revealed isometric crystals, adhering to the aluminoferrite grains, with refractive index slightly higher than that of the dispersed crystals. Preparation Fss-6 reacted very slowly, yielding a few well formed hexagonal plates occurring mostly as a fringe around the original grains. Isometric crystals were not observed, but the $x$-ray pattern showed a few weak lines that could be attributed to this phase.

In view of the foregoing results, a re-examination of the solutions in regard to $\mathrm{Fe}_{2} \mathrm{O}_{3}$ concentration was indicated. Filtrates from some of the reaction mixtures were concentrated by evaporation and tested for iron by the thiocyanate method in comparison with a standard ferric chloride solution. The iron content was found to be in the range of 0.02 to $0.05 \mathrm{mg} \mathrm{Fe}_{2} \mathrm{O}_{3}$ per liter, without consistent trend with composition of the aluminoferrite. Although this is lower by several orders of magnitude than the concentration of $\mathrm{Al}_{2} \mathrm{O}_{3}$, it has an appreciable effect on the composition of the precipitate. The crystals typically were well formed, either dispersed or attached to the wall of the vessel, not attached to grains of the anhydrous aluminoferrite (except as noted above); hence there can be little doubt that they were precipitated from the solution phase, not formed at the solid-liquid interface.

\subsection{Hydration in Paste Form}

The reactions described above occurred under conditions permitting the $\mathrm{Al}_{2} \mathrm{O}_{3}$, most of the $\mathrm{CaO}$, and a trace of $\mathrm{Fe}_{2} \mathrm{O}_{3}$ to go into solution, with ultimate disappearance of the original solid phase, leaving most of the $\mathrm{Fe}_{2} \mathrm{O}_{3}$ (possibly hydrated) with a little adsorbed $\mathrm{CaO}$ in finely dispersed form. These conditions are far different from those existing in cement pastes. A brief study of hydration with small amounts of water was therefore made. A small amount of the powdered sample (fine fraction) was placed in a weighed glass tube, the tube was reweighed, a few drops of water were added, and the tube was quickly sealed in a flame and again reweighed. The ratio of water to solid ranged from 0.5 to 1.1. The tubes were stored at three different temperatures, 1,25 , and $45{ }^{\circ} \mathrm{C}$, all $\pm 1{ }^{\circ} \mathrm{C}$, for 2 months. The contents were then dried and examined microscopically and by x-ray dif- 
fraction. Most of the tubes were found to be cracked, probably owing to expansion of the contents during hydration. Hydration appeared to be essentially complete or at least far advanced in all cases, thus it is apparent that the cracking had not interfered seriously with the process. However, a few of the x-ray diffraction patterns showed evidence of small amounts of calcium aluminate monocarbonate, probably indicating that some carbon dioxide had entered through the cracks.

The phases identified in the hydration products are listed in table 9. At $1{ }^{\circ} \mathrm{C}, \mathrm{C}_{2} \mathrm{AH}_{8}$ is the major hydration product at the high-alumina end of the series. The high-iron members give the tetracalcium compound, presumably a solid solution containing both ferric oxide and alumina. At $25^{\circ} \mathrm{C}$, the isometric phase predominates, but is accompanied by $\mathrm{C}_{2} \mathrm{AH}_{8}$ in Fss-1 and by the other hexagonal phase in Fss-5, while in Fss-6 and $\mathrm{C}_{2} \mathrm{~F}-1$ only the hexagonal is present. At $45{ }^{\circ} \mathrm{C}$, the isometric phase was the only hydrate identified in the first five; the $\mathrm{C}_{2} \mathrm{~F}$ product showed only the hexagonal, and Fss-6 yielded both.

TABle 9. Phases present in hydration products of aluminoferrites after hydration for 2 months in paste form

\begin{tabular}{|c|c|c|c|}
\hline $\begin{array}{l}\text { Sample } \\
\text { No. }\end{array}$ & Stored at $1^{\circ} \mathrm{C}$ & Stored at $25^{\circ} \mathrm{C}$ & Stored at $45{ }^{\circ} \mathrm{C}$ \\
\hline Fss-1 & $\begin{array}{l}\text { (a) } \\
\mathrm{C}_{2} \mathrm{AH}_{8} ; \text { little carb; } \\
\text { little Fss; some } \\
\text { unidentified }\end{array}$ & $\begin{array}{l}\mathrm{HG} \text {; little } \mathrm{C}_{2} \mathrm{~A} \mathrm{H}_{8} \\
\text { little Fss }\end{array}$ & HG; very little Fss \\
\hline Fss-2 & Fss; little $\mathrm{C}_{2} \mathrm{AH}_{8} \ldots$ & HG; trace carb & $\mathrm{HG}$; trace Fss \\
\hline Fss-3 & $\begin{array}{l}\text { Fss; carb; little } \\
\mathrm{C}_{2} \mathrm{AH} \mathrm{H}_{8} ; \text { unidenti- } \\
\text { fied material }\end{array}$ & $\begin{array}{l}\text { HG; little Fss; un- } \\
\text { identified ma- } \\
\text { terial }\end{array}$ & $\begin{array}{l}\text { HG; trace Fss; un- } \\
\text { identified material }\end{array}$ \\
\hline Fss-4 & $\mathrm{C}_{4}(\mathrm{~A}, \mathrm{~F}) \mathrm{H}_{n} ;$ trace & HG; trace Fss...... & $\mathrm{HG}$ \\
\hline Fss-5 & $\mathrm{C}_{4}(\mathrm{~A}, \mathrm{~F}) \mathrm{H}_{n} ; \mathrm{FsS}_{\ldots}$ & $\begin{array}{l}\mathrm{HG} ; \mathrm{C}_{4}(\mathrm{~A}, \mathrm{~F}) \mathrm{H}_{n} ; \\
\text { little carb; un- } \\
\text { identified mate- }\end{array}$ & $\begin{array}{l}\text { HG; unidentified } \\
\text { material }\end{array}$ \\
\hline Fss-6 & $\begin{array}{l}\mathrm{C}_{4}(\mathrm{~A}, \mathrm{~F}) \mathrm{H}_{n} ; \text { little } \\
\text { hematite; trace } \\
\text { carb. }\end{array}$ & $\begin{array}{l}\mathrm{C}_{4}(\mathrm{~A}, \mathrm{~F}) \mathrm{H}_{n} ; \mathrm{Fss} ; \\
\text { unidentified } \\
\text { material }\end{array}$ & $\begin{array}{l}\mathrm{HG} ; \mathrm{C}_{4}(\mathrm{~A}, \mathrm{~F}) \mathrm{H}_{n} ; \\
\text { little Fss(?) }\end{array}$ \\
\hline $\mathrm{C}_{2} \mathrm{~F}-1$ & $\begin{array}{l}\mathrm{C}_{4} \mathrm{FH}_{n} \text {; unidenti- } \\
\text { fied material }\end{array}$ & $\begin{array}{l}\mathrm{C}_{4} \mathrm{FH}_{n} \text {; unidenti- } \\
\text { fied material }\end{array}$ & $\begin{array}{l}\mathrm{C}_{4} \mathrm{FH}_{n} ; \text { unidentified } \\
\text { material }\end{array}$ \\
\hline
\end{tabular}

a $\mathrm{HG}=$ hydrogarnet $\left(3 \mathrm{CaO} \cdot\left(\mathrm{Al}_{2} \mathrm{O}_{3}, \mathrm{Fe}_{2} \mathrm{O}_{3}\right) \cdot 6 \mathrm{H}_{2} \mathrm{O}\right)$,

carb $=3 \mathrm{CaO} \cdot \mathrm{Al}_{2} \mathrm{O}_{3} \cdot \mathrm{CaCO}_{3} \cdot 11 \mathrm{H}_{2} \mathrm{O}$,

$\mathrm{Fss}=$ unaltered anhydrous material,

"trace" indicates barely detectable by x-ray,

$\mathrm{C}=\mathrm{CaO}$,

$\mathrm{A}=\mathrm{Al}_{2} \mathrm{O}_{3}$,

$\mathrm{H}=\mathrm{H}_{2} \mathrm{O}$.

In general, the x-ray diffraction lines of the isometric phase were sharper the higher the temperature and the higher the alumina content. The patterns of the hexagonal phases were characterized by a very strong line from the 001 plane.

The cell constant, $a_{0}$, for the isometric phase was measured on partial x-ray diffraction patterns comprising the 431,521 , and 611 reflections, with tungsten present as internal standard. In figure 5 the cell constants for the 45-deg products are plotted against the composition of the anhydrous starting material, expressed as $\frac{\mathrm{Fe}_{2} \mathrm{O}_{3}}{\mathrm{Al}_{2} \mathrm{O}_{3}+\mathrm{Fe}_{2} \mathrm{O}_{3} \text { (molar) }}$.

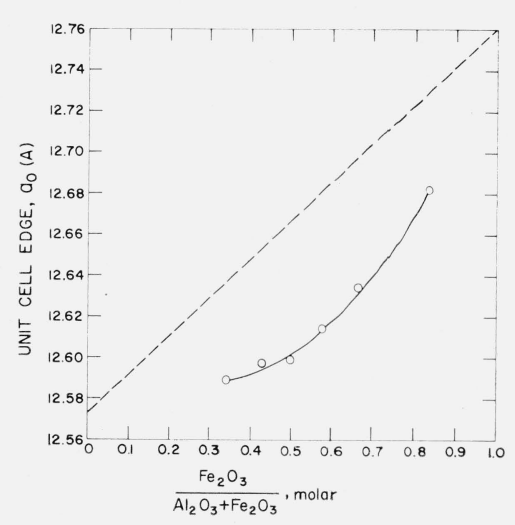

Figure 5. Cell constant of isometric phase in product of paste hydration of calcium aluminoferrites as related to composition of anhydrous material.

exact relationship between cell size and composition of the isometric phase is not known, but it is believed to be not far from linear. In the diagram, the dashed line represents a linear relationship from $\mathrm{C}_{3} \mathrm{AH}_{6}$ to $\mathrm{C}_{3} \mathrm{FH}_{6}$, based on the cell constants 12.573 for $\mathrm{C}_{3} \mathrm{AH}_{6}$ and 12.76 for $\mathrm{C}_{3} \mathrm{FH}_{6}$, the latter from data of Roberts reported by Jones [7]. The actual curve is below the dashed line, indicating that the hydration product is poorer in iron than the starting material.

The refractive index of the isometric phase in the hydration products also varies with composition, but because of other phases present it was difficult to determine with any precision. It ranged from 1.61 for Fss-1 up to about 1.67 for Fss-6.

\section{Discussion}

\subsection{Nature of the Reaction}

In the solution experiments described above, the ratio of water to solid was of the order of 1000:1. When the ferrite phase in portland cement is hydrated, in practice, the water-cement ratio is less than $1: 1$. The series of hydration experiments using small amounts of water was intended to simulate practical conditions, with the important exception that the other cement compounds were absent. The two conditions of solid: water ratio are widely divergent, but they coincide at one point, the instant of the first contact between solid and water, when the concentration of solute in the liquid phase is nil.

The leaching experiments described under section 3.1 demonstrated that the reaction begins practically instantaneously on contact. Exactly what takes place at the interface during the first fraction of a second is not revealed, but it is shown that $\mathrm{CaO}$ and $\mathrm{Al}_{2} \mathrm{O}_{3}$ go into solution immediately, leaving nearly all of the $\mathrm{Fe}_{2} \mathrm{O}_{3}$ in the solid state. The $\mathrm{Fe}_{2} \mathrm{O}_{3}$ is not totally insoluble, but the concentration is only about $0.05 \mathrm{mg} /$ liter or less. If the $\mathrm{Fe}_{2} \mathrm{O}_{3}$ goes into solution initially along with the $\mathrm{CaO}$ and $\mathrm{Al}_{2} \mathrm{O}_{3}$, it must coagulate or crystallize into particles large enough to be retained on the filter, all within a fraction of a second. Such an explanation appears improbable. 
It is more likely that the calcium and aluminum atoms are removed from the outer layers, by some unknown mechanism, leaving the iron at least momentarily in the original crystal structure. A small amount of calcium remains with the iron, the ratio being a function of the concentration of the solution in contact. ${ }^{3}$

Although the aluminoferrites do not dissolve congruently, the reaction rate is influenced in a similar manner by the concentration of the reaction products. That is, the rate decreases as the concentration of $\mathrm{CaO}$ and $\mathrm{Al}_{2} \mathrm{O}_{3}$ in solution increases. When the solid is leached with a stream of water, the concentration always remains low. Continued leaching should ultimately leave a residue of almost pure $\mathrm{Fe}_{2} \mathrm{O}_{3}$ (or a hydrate). When the solid is caused to react with a large volume of water, and the liquid phase is not removed, the concentration of $\mathrm{CaO}$ and $\mathrm{Al}_{2} \mathrm{O}_{3}$ in solution builds up to the point of supersaturation with respect to one or more of the calcium aluminate hydrates, whereupon precipitation will occur, though not necessarily at once. The concentration at which this happens depends on the temperature, the $\mathrm{CaO}: \mathrm{Al}_{2} \mathrm{O}_{3}$ ratio, and the particular solid phase formed. The complexities of the phase equilibrium relations in the $\mathrm{CaO}-\mathrm{Al}_{2} \mathrm{O}_{3}-\mathrm{H}_{2} \mathrm{O}$ system have been reviewed by Jones [7]. The experimental proportions in the present study were chosen to avoid precipitation of the hexagonal aluminates, but in a few cases, at 25 and $45^{\circ} \mathrm{C}$, it was apparent that a slight amount of precipitation had occurred, whether of hexagonal or isometric crystals being undetermined. At 70 and $100{ }^{\circ} \mathrm{C}$, the precipitate was the isometric hydrate.

Hydration at low water-solid ratios, simulating paste hydration, may be assumed to follow the same course at first, but the concentration increases to the supersaturation range very rapidly, probably within the first minute for the more reactive members. In agreement with this assumption, preparations Fss-1 and Fss-2 exhibited what might be termed "flash set", while the rest of this series took increasingly long to stiffen as the $\mathrm{Fe}_{2} \mathrm{O}_{3}$ content increased. The initial stiffening is assumed to result from precipitation of a calcium aluminate hydrate.

Once the paste has stiffened, the movement of the liquid phase and the diffusion of ions through it must be greatly restricted. Hydration probably continues, however, provided sufficient water is present, until all the original anhydrous material has reacted, just as in the case of the other constituents of cement clinker.

The reaction products resulting from paste hydration are not the same as those produced by hydration in a large amount of water. When a small amount of the anhydrous material is dispersed in water, a supersaturated solution is formed, from which one or more hydrated phases then precipitate. At the higher temperatures, the precipitate contains the isometric phase, $3 \mathrm{CaO} \cdot\left(\mathrm{Al}_{2} \mathrm{O}_{3}, \quad \mathrm{Fe}_{2} \mathrm{O}_{3}\right) \cdot 6 \mathrm{H}_{2} \mathrm{O}$.

\footnotetext{
3 The iron-free constituents of cement clinker, $\mathrm{C}_{3} \mathrm{~S}, \mathrm{C}_{2} \mathrm{~S}$, and $\mathrm{C}_{3} \mathrm{~A}$, react in a different manner when subjected to the same leaching procedure, the ratio of components in the filtrate being approximately the same as in the solid compound.
}

The ratio of $\mathrm{Fe}_{2} \mathrm{O}_{3}$ to $\mathrm{Al}_{2} \mathrm{O}_{3}$ in this phase is of the order of 1 to 10 , and appears not to vary with the ratio in the anhydrous material. The ratio in the hydrated phase is therefore assumed to be controlled by the relative concentrations of the two components in solution. The ratio of $\mathrm{Fe}_{2} \mathrm{O}_{3}$ to $\mathrm{Al}_{2} \mathrm{O}_{3}$ in solution was found to be at least as low as 1 to 4000, with no apparent dependence on the composition of the anhydrous phase; thus the precipitate is strongly beneficiated with respect to iron.

In contrast, paste hydration yields an isometric phase in which the $\mathrm{Fe}_{2} \mathrm{O}_{3}: \mathrm{Al}_{2} \mathrm{O}_{3}$ ratio varies with that in the anhydrous starting material. However, they are not equal, the isometric hydrate being always poorer in iron than the starting material. These results are not entirely in agreement with those reported by Chatterji and Jeffery [9], who found no replacement of $\mathrm{Al}$ by $\mathrm{Fe}$ in the isometric phase when $\mathrm{C}_{4} \mathrm{AF}$ was hydrated in paste condition. The data reported in the present paper indicate replacement of $\mathrm{Al}$ by Fe sufficient to enlarge the unit cell dimensions by about 0.2 percent in a comparable hydration of $\mathrm{C}_{4} \mathrm{AF}$. Because of minor differences in experimental conditions and in $x$-ray diffraction equipment, it is impossible to say, at present, whether this slight difference in results is apparent or real. There is agreement to this extent, at least, that even under conditions of paste hydration, the anhydrous structure is broken down and the components are selectively combined in the hydrate. Consideration of the stoichiometry of the reaction shows that this is necessary, since there is insufficient lime to combine with all the $\mathrm{Fe}_{2} \mathrm{O}_{3}$ and $\mathrm{Al}_{2} \mathrm{O}_{3}$ to form the isometric (hydrogarnet) phase. The effect of introducing excess lime into the paste was investigated by Chatterji and Jeffery [9], who obtained a cubic phase with unit cell dimension about 0.5 percent larger than that of $\mathrm{C}_{3} \mathrm{AH}_{6}$ by hydrating a paste of $\mathrm{C}_{4} \mathrm{AF}$ with added lime.

The results obtained with preparation $\mathrm{Fss}^{-5} 5$ in water-solid ratio of 100 to 1 (table 8) show some indication of what might be termed a transition stage between the free dispersion and the paste conditions. Here there was evidence of formation of the isometric phase both by precipitation from solution and by growth on the edges of the parent material. The latter crystals were apparently richer in iron than the former, but still contained less iron than those formed by paste hydration of the same anhydrous preparation.

The products of hydration under the two extremes of reaction conditions also differ in respect to the hexagonal plate phases. Paste hydration permits formation of the tetracalcium series, $4 \mathrm{CaO} \cdot\left(\mathrm{Al}_{2} \mathrm{O}_{3}\right.$, $\left.\mathrm{Fe}_{3} \mathrm{O}_{3}\right) \cdot n \mathrm{H}_{2} \mathrm{O}$, from the iron-rich aluminoferrites, even at $45^{\circ} \mathrm{C}$ in the case of Fss-6 and the $\mathrm{C}_{2} \mathrm{~F}$ end member (table 9). This phase was not observed in the hydration products precipitated from solution. This fact is understandable, since the $\mathrm{CaO}$ in solution never reached the high concentration necessary for precipitation of the tetracalcium series. It is reasonable to assume that in paste hydration the slow diffusion of the ions allows the concentration to build up sufficiently for formation of the tetracalcium series. 
The $x$-ray pattern of the hydrated tetracalcium aluminate-ferrite solid-solution series varies with composition but the displacement of the diffraction lines is relatively small, and the relationship not well established. The situation is complicated by the existence of two forms of $\mathrm{C}_{4} \mathrm{AH}_{13}$ with slightly different spacings. For these reasons, no attempt was made to correlate the composition of the hexagonal plate phase with the composition of the parent material.

At the lower temperatures, the hexagonal plate phase $\mathrm{C}_{2} \mathrm{AH}_{8}$ (or its limited solid solution) was observed in the paste hydration products of the more alumina-rich members of the series. Similar plates were observed in stirred suspensions of the same preparations, also at the lower temperatures. Although too few for positive identification, they may be assumed to have been the same phase, since the $\mathrm{CaO}$ concentration was too low to permit precipitation of the tetracalcium compound of similar appearance. It would be interesting to know whether this phase also takes up $\mathrm{Fe}_{2} \mathrm{O}_{3}$ into solid solution, as does the hydrogarnet. Although there has been some speculation as to the possibility of such substitution [7] there appears to be no conclusive evidcnce that it occurs, and the question remains unanswered for the present.

It is of some interest to note (see table 9) that on hydration in paste form at $25^{\circ} \mathrm{C}$, the hexagonal plate phases appeared only at the high-alumina and the high-iron oxide ends of the series (dicalcium and tetracalcium compounds, respectively). The intermediate members, Fss -2 and Fss -3 , yielded only the isometric phase.

The nature of the ferric oxide residue was not established. In a few of the precipitates examined by x-ray diffraction, numerous weak lines corresponding to the pattern of hematite were observed. In many other patterns only one or two lines attributable to hematite appeared, and in still others, none at all, even though the residue was known to contain a large amount of iron oxide not otherwise accounted for. Patterns of the hydrated ferric oxides were not observed. From these facts it may be inferred that the residual $\mathrm{Fe}_{2} \mathrm{O}_{3}$ is amorphous at first (with a variable amount of adsorbed $\mathrm{CaO}$ ) and that it gradually changes to hematite.

It should be emphasized that the observations on the reactions of the aluminoferrites on paste hydration, as reported here, do not necessarily indicate that these materials would behave in the same way in the hydration of cement, in the presence of silica, calcium sulfate, excess calcium hydroxide, and other substances.

\subsection{Rate of Reaction}

The determination of reaction rates in heterogeneous systems is a complicated matter even for simple reactions occurring under carefully controlled conditions. The reaction between water and the aluminoferrites is not simple, and it appeared inadvisable to attempt to derive mathematical expressions for the true reaction rates. However, it was desirable to obtain at least an approximate idea of the variation of rate of reaction with composition.

The rate of solution of a solid in a liquid may be assumed to vary linearly with the area of the interface. As the reaction proceeds, both the volume and the surface area of the solid phase decrease. At the start, the percentage decrease in area is two-thirds that of the volume (which in turn is equal to that of the mass of the solid phase) assuming particles of regular shape and uniform size. Neither assumption holds in the present case. Furthermore, the solid does not dissolve congruently, and nothing is known as to the inhibiting effect of the residue. All that can be said on this point is that the surface area factor should cause a gradual decrease in reaction rate.

When a solid dissolves congruently, the rate decreases exponentially because of the increasing concentration of solute. In the present case, the solid does not dissolve congruently. It was shown experimentally that the reaction is slower in the presence of $\mathrm{Ca}(\mathrm{OH})_{2}$ in solution, and it may reasonably be assumed that dissolved $\mathrm{Al}_{2} \mathrm{O}_{3}$ would have a similar effect. The dissolution of the aluminoferrite, unlike that of an ordinary soluble salt, does not reach an equilibrium concentration and then stop. Hydrated crystalline phases are precipitated from solution, permitting the decomposition of the anhydrous material to proceed to completion. These factors influence the reaction rate to an unpredictable extent. The rate was shown to fall off rapidly as the reaction progressed, and the concentration factor undoubtedly is the chief cause of the decrease.

Closely allied to the concentration factor is the rate of diffusion of solute away from the reaction zone, which in turn is controlled in large part by the rate of stirring. An attempt was made to subject all the suspensions to the same degree of agitation, but strict uniformity was not attained.

In view of the complicating factors discussed above, it is evident that any attempt to estimate reaction constants would not have much meaning. Therefore, in comparing the reaction velocities of the aluminoferrites, the concentration attained after a fixed period of stirring was arbitrarily taken as a measure of the reactivity. Under these experiental conditions, as shown in figure 4 , the reactivity is strongly dependent on composition, increasing with the $\mathrm{Al}_{2} \mathrm{O}_{3}: \mathrm{Fe}_{2} \mathrm{O}_{3}$ ratio.

The kinetics of paste hydration are quite different. Here the diffusion of water molecules or the solute ions, or both, must be the most important factor in controlling the rate. Although there was but one series of experiments of this type, and all were of the same duration, it appears that the hydration of the different members of the series proceeded at something near the same rate, regardless of composition.

\section{Summary}

The initial reaction occurring immediately on contact between water and a member of the calcium aluminoferrite solid solution series is one of incongruent solution. The alumina, most of the calcium 
oxide, and a trace of iron oxide pass into solution, and a residue of iron oxide (probably amorphous) with adsorbed calcium oxide remains.

At sufficiently high dilution, the reaction will proceed to completion. More concentrated suspensions give rise to supersaturation followed by precipitation. The major precipitated phase at room temperature is $2 \mathrm{CaO} \cdot \mathrm{Al}_{2} \mathrm{O}_{3} \cdot 8 \mathrm{H}_{2} \mathrm{O}$ (or a solid solution). At $70^{\circ} \mathrm{C}$ the precipitate is chiefly a phase of the hydrogarnet type of approximate composition $3 \mathrm{CaO} \cdot 0.9 \mathrm{Al}_{2} \mathrm{O}_{3} \cdot 0.1 \mathrm{Fe}_{2} \mathrm{O}_{3} \cdot 6 \mathrm{H}_{2} \mathrm{O}$.

The rate of reaction varies greatly with the composition of the aluminoferrite, being most rapid for the preparation highest in alumina.

The rate of reaction increases with temperature, the relative increase being more pronounced for the preparations high in iron oxide.

Hydration of the aluminoferrites in paste form progresses in a different manner. The hydrogarnet phase produced varies in composition with the aluminoferrite starting material, approaching but not reaching the $\mathrm{Fe}_{2} \mathrm{O}_{3}: \mathrm{Al}_{2} \mathrm{O}_{3}$ ratio in the anhydrous material. At the lower temperatures, $2 \mathrm{CaO} \cdot \mathrm{Al}_{2} \mathrm{O}_{3}$. $8 \mathrm{H}_{2} \mathrm{O}$ (or its limited solid solution) is produced from the aluminoferrite highest in alumina, hydrogarnet from intermediate members, and $4 \mathrm{CaO} \cdot\left(\mathrm{Al}_{2} \mathrm{O}_{3}\right.$, $\left.\mathrm{Fe}_{2} \mathrm{O}_{3}\right) \cdot n \mathrm{H}_{2} \mathrm{O}$ from those highest in iron oxide, The excess $\mathrm{Fe}_{2} \mathrm{O}_{3}$ remaining is believed to form hematite, possibly after an intermediate amorphous stage. The rate of hydration is less dependent on composition than is the case with highly dispersed suspensions.

Preparation of the main series of aluminoferrites and most of the work described under section 3.2 were done by Philip H. Bowles, student trainee at the National Bureau of Standards during one summer. X-ray diffraction patterns were made by H. E. Swanson and J. De Groot of the Crystallography Section. The assistance of these persons is gratefully acknowledged.

\section{References}

[1] W. C. Hansen, L. T. Brownmiller, and R. H. Bogue, Studies on the system calcium oxide-alumina-ferric oxide, J. Am. Chem. Soc. 50, 396-406 (1928).

[2] R. W. Nurse, Phase equilibria and constitution of portland cement clinker, Proc. Fourth International Symposium on the Chemistry of Cement, NBS Mono. 43 (1962), pp. 9-37.

[3] D. K. Smith, Crystallographic changes with the substitution of aluminum for iron in dicalcium ferrite, Acta Cryst. 15, 1146-1152 (1962).

[4] T. F. Newkirk and R. D. Thwaite, Pseudoternary system calcium oxide-monocalcium aluminate-dicalcium ferrite, J. Res. NBS 61, 233-245 (1958).

[5] E. P. Flint, H. F. MeMurdie, and L. S. Wells, Hydrothermal and x-ray studies of the garnet-hydrogarnet series and the relationship of the series to hydration products of portland cement, J. Res. NBS 26, 13-33 (1941).

[6] G. Malquori and V. Cirilli, The hydrated calcium ferrites, and the complexes that originate from tricalcium ferrite by association with different salts of calcium (Note 4), (in Italian), Ric. Sci. 14, 78-84 (1943).

[7] F. E. Jones, Hydration of calcium aluminates and ferrites, Proc. Fourth International Symposium on the Chemistry of Cement, NBS Mono. 43 (1962), pp. 204-246.

[8] M. H. Roberts, New calcium aluminate hydrates, J Appl. Chem. 7, 543-546 (1957).

[9] S. Chatterji and J. W. Jeffery, Studies of early stages of paste hydration of cement compounds, I, J. Am. Ceram. Soc. 45, 536-543 (1962).

[10] H. G. Midgley, D. Rosaman, and K. E. Fletcher, X-ray diffraction examination of portland cement clinker, Proc. Fourth International Symposium on the Chemistry of Cement, NBS Mono. 43 (1962) pp. 69-74.

[11] Method 1101.1, Federal Test Method Standard No. 158 a $(1960)$

[12] Method 2101.1, Federal Test Method Standard No. $158 \mathrm{a}(1960)$.

(Paper 68A5-293 